\title{
Hedging of Sales by Zero-cost Collar and its Financial Impact
}

\author{
Bartoňová Marie
}

\begin{abstract}
The zero-cost option structures appeared in 90's and became popular tool of hedging. They come of combination of standard and also exotic option. The paper deals with the most famous of them - zero-cost collar strategy. It is researched from sales hedging point of view, so the paper proposes an application of the strategy in hedging against an exchange rate drop of the currency at a future date. The goal of paper is certification of theoretical findings in particular option contracts for sales hedging and a financial impact analysis of reached results. The paper shortly devotes also to find out offer of products in zero-cost option area and their availability and expediency for Small and Medium-sized enterprises.
\end{abstract}

Key words: zero-cost option strategies, put option, call option, exchange rate, strike price, hedging,

\section{INTRODUCTION}

A fluctuation of currency exchange rate means constant risk for the Czech companies. The appreciation of the Czech currency and mainly considerable volatility of exchange rate can lead to significant losses of enterprise value. Exchange rate course in last months has signified the negative impact more on importers but it is not definite for exporters at current change of trend. Both entities will try to hedge against the currency risk. One of the hedging possibilities is using of options, although the forwards are always the most used. This possibility was not often used considering relatively high price of option, by small and middle-sized enterprises then only rarely. However, some companies use options. Zero-cost options account for the largest share of options.

An offer of option with zero initial costs, or commonly used zero-cost option, looks attractive for enterprises. Prima facie meets the forwards which suit them, it means a way of hedging without initial costs, but also what they valuate on option, it means absence of obligation to sell or buy an underlying asset at maturity day. A question is whether it is really so advantageous and whether it is able to hedge a risk.

The banks offer all series of those and they are individually able to create a structure according to requests of clients. Which particular option structure the company will choose, it depends on its stand on risk, on financial expectation and its estimation of future exchange rate movement. As follows the option structures occur with different profit profile. They use various types of options for it. Because the Czech economy is strongly export directed, this article devotes to option structures and their evaluation from exporters point of view.

The goal of this paper is to clarify working of zero-cost collar, to analyse and quantify a financial impact of actual using option in an enterprise. The enterprises can benefit from advantage of zero-cost collar when they use it, it means a limitation of loss at exchange rate drop of the 
currency. In the same way, they can suffer huge loss at the exchange rate increase. The practical examples can show how it is probable that the hedging by collar will be effective.

\section{LITERATURE REVIEW}

Options are probably the most versatile trading instrument ever invented. To make option strategies profitable it is necessary to know not only potential profit that can be reached by well-conceived and a time-tested strategies, but also to understand how these investment instruments work and what risk they include (Fontanills, 2005). It is similarly valid as for hedging. At first, it is necessary to know general basics until they can be used.

Option strategies can be found in several publications. Analytical forms and graphs of the profit function are described in papers of Ambrož (2002), Jílek (2005), Hull (2002) and others. There are strategies mostly formed by vanilla options. The works of Šoltés (2010) and Šoltés and Rusnáková (2010) deals with structured products.

Although hedging by options is not broadly used as forwards, it has gained popularity by the establishment of zero-cost option structures. A package with zero cost consists of standard option usually where underlying assets are foreign currencies, currency futures, commodities, securities, or securities in other than domestic currency.

Hull (2002) states that a package is a portfolio consisting of standard European calls, standard European puts, forward contracts, cash, and the underlying assets itself. Often a package is structured by traders so that it has zero cost initially. An example is a range-forward contract. A short range-forward contract consists of a long position in a put with a low strike price. X1, and a short position in a call with a high strike price, X2. It guarantees that the underlying asset can be sold for a price between X1 and X2 at the maturity of the options. A long rangeforward contract consists of a short position in a put with the low strike price, X1, and a long position in a call with the high strike price, X2 at the maturity of the options. The price of the call equals the price of the put when the contract is initiated. Figure 1 shows the payoff from short range-forward contracts. As X1 and X2 are moved closer to each other, the price that will be received or paid for the asset at maturity becomes more certain. In the limit when X1 $=\mathrm{X} 2$, the range-forward contract becomes a regular forward contract.

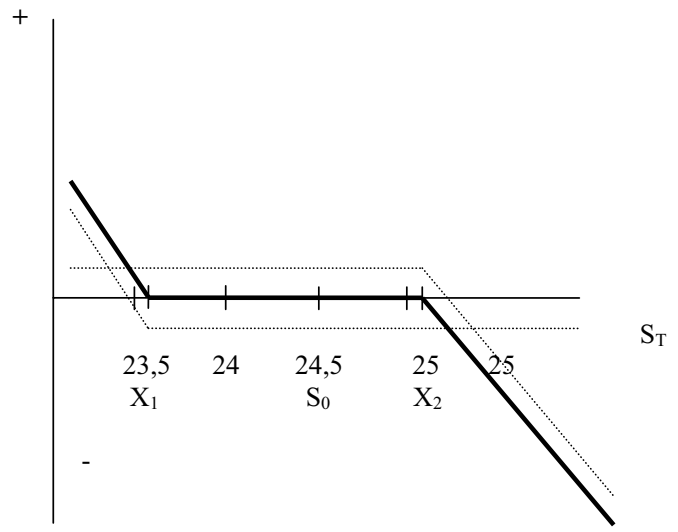

Fig. 1 - Payoff of strategy short range forward. Source: own research 
This strategy consists of standard currency options, where the underlying asset is foreign currency, for case of currency risk hedging follows due to a possible drop in exchange rate. The strategy will be profitable when exchange rate decreases bellow X1 level at maturity day. However, this profit will be neutralized by decreased value of receivable in foreign currency. The exporter would lose from option strategy in case of strong exchange rate appreciation under level $\mathrm{X} 2$, although the value of his receivable in foreign currency would increase on the contrary.

The total profitable position (payoff) of both contracts is changed by including the value of receivable (more precisely taking up of long position in contract). Function dependency of profit or loss of this strategy is called „range forward“.

Described strategy is called not only as range forward, but also as zero-cost collar, zero-cost cylinder, or zero-cost fence.

Collars which combine a long put with a short call, reduce the volatility and loss risk by about 65 percent and offer the best return-to-risk- ratios. Zero-cost collars, which combine a put spread with a short call, lower the risk by half as much, but preserve long-term returns. The outright selling of the OTM calls benefits from the same trade-off while forgoing the downside protection of the collars. OTM call strategies show high return-to-risk statistics, but their risk reductions fall short of 30 percent (Dubil, 2010)

Short-term exposure seems to be relatively well hedged where considerable evidence of longterm exposure is found (Muller and Verschoor, 2006). Finley and Pettit (2011) state that symmetrical hedges are ill suited to longer-dated hedge horizons and more volatile underlying assets, which increases the risk of the hedge going underwater.

Sophisticated methods of hedging using zero-cost option strategies are proposed, for example Inverse Vertical Ratio Put Spread Strategy in hedging against a price drop of the underlying asset (Šoltés and Amaitiek, 2010), application of the Short Put Ladder Strategy in hedging against a price drop of the underlying asset and its new way of an option strategy formation (Šoltés and Amaitiek, 2010), the Short Call Ladder Strategy - new approach to the formation in hedging against a price rise of the underlying asset (Amaitiek et al, 2010).

Chung et al. (2010) included the standard options and binary options into modified static

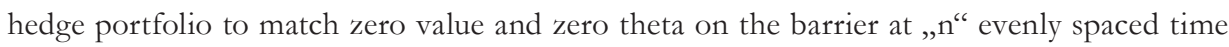
points. The numerical results indicated that their modified Derman-Ergener-Kani method significantly improves not only the hedging performance but also the speed of convergence to the continuous barrier option price.

The sophisticated professional investors play a more dominant role in financial market and they used to. But there is no clear theoretical presumption that the rise of sophisticated investors should necessarily be beneficial to the market efficiency (Stein, 2009).

Not only, it is not clear that the development of sophisticated option strategies is beneficial for financial market but it is not clear also for enterprises. Khil (2010) researched the using of option strategies including Knock-in and Knock-out options in Korean enterprises. Research shows up that if these option holders had assessed the risk levels with and without these options by using standard risk measures, then many option contracts would not have been justifiable from the beginning. Even if a hedging instrument is justifiable at purchase time, its risk level should be continuously assessed. The risk level may change over time. 
Even the zero-cost options should not be used automatically. Surprisingly, it is still difficult today for managers to get approval to spend money to buy „insurance“. However, „free“ insurance does not garner the same level of scrutiny, or require the same levels of approval. It is also reason why collars and participating forwards tend to be the most popular (Finley and Pettit, 2011).

\section{RESEARCH AND METHODS}

When enterprises know currency options and their functionality, then they can use hedging transaction to plan and to mitigate the risk involved in exchange rate fluctuations. To clarify running of sales hedging by zero-cost option it has been chosen a model example of enterprise.

There is an example of the Czech exporter enterprise which has a receivable in the amount of EUR 100000 and sales income from buyer is expected in time T (it can be maturity day, common time of payment by this customer...). This receivable is booked in accounting accordingly accounting rules - the enterprise uses daily exchange rate. When current exchange rate of $\check{C} \mathrm{NB}$ is $24,5 \mathrm{EUR} / \mathrm{CZK}$, then the enterprise has the revenue in amount $2450000 \mathrm{CZK}$ in accounting. The exporter would need to change EUR for CZK after receiving of payment. To avoid the loss involved in exchange rate fluctuations he decides to hedge by currency option.

Because an exporter is expecting decrease in exchange rate he performs:

1. purchase of put option

2. sale of call option.

A put is set at $3 \%$ below the current exchange rate of $\mathrm{CNB}$, alternatively also $1,5 \%$ and $8 \%$. The maturity was chosen at 3 months, alternatively also 6 and 12 months. The call price is set by the bank so that it equals the value of the put. "Parity" is then said to be achieved. The value of the put and call are about equal and now form a "collar" around the accounting exchange rate. Because both options have equal value there is no premium.

The empiric method of scientific research was used. To verify the theoretical findings 5 banks were requested to quote strike in contract, i.e. to determine price of call option to required strike of put option. They should state also market value which they proceed from. Three banks, Citibank, UniCredit Bank a HSBC sent their offer of call strike price. Individual contracts were left to their maturity date. Then the assessment was made.

The goal of research was certification of theoretical findings in particular option contracts, certification of hedging purpose fulfilment, which means using of put option. Financial impact of using zero-cost collar has been analysed. Next goal was finding out what offer of product exists, and whether using of zero-cost option is available also for small and medium-sized enterprises. Therefore a short questionnaire was sent to the banks. It focused on conditions of zero-cost option provision. Information was obtained also from the web sites of the banks. 


\section{RECEIVABLE HEDGING BY ZERO-COST OPTION}

\subsection{The offer of Citibank as of date 25.3.2011 - Corridor Forward}

Starting situation:

Receivable in accounting as of March, 25, 2011100000 EUR, or 2452500 CZK,

Exchange rate of ČNB as of March, 25, 2011 24,525 CZK/EUR,

Due date of receivable

3 months, alternatively

Due date of receivable

6 months,

Due date of receivable

12 months.

Citibank states market value 24,55 EUR/CZK and quotes strike price of call option for particular maturities like this:

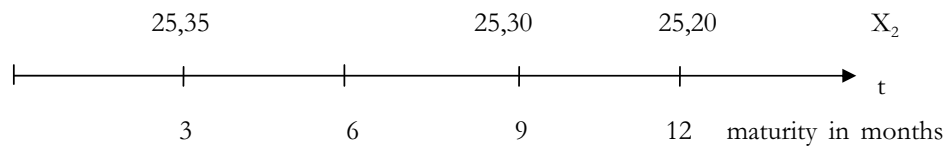

t ........ number of months to option maturity

$\mathrm{X}_{2} \ldots \ldots$ strike of call option

Onwards it is analysed with a 3 month's maturity variant. It can be summarized into following table 1. 
Tab. 1 - Evaluation of variations at expire date - Citibank, maturity 3 M. Source: own research

\begin{tabular}{|c|c|c|c|c|c|c|c|c|}
\hline $\begin{array}{c}\text { Bank } \\
\text { ex.rate } \\
\text { (ST) }\end{array}$ & $\mathrm{S}_{1}$ & $\mathrm{~S}_{2}$ & $\mathrm{~S}_{3}$ & $\mathrm{~S}_{4}$ & $\mathrm{~S}_{5}$ & $\mathrm{~S}_{6}$ & $\mathrm{~S}_{7}$ & BEV \\
\hline & 23,5 & 23,78 & 24,2 & 24,525 & 25 & 25,35 & 25,5 & 25,60606 \\
\hline Invoice & 2452500 & 2452500 & 2452500 & 2452500 & 2452500 & 2452500 & 2452500 & 2452500 \\
\hline $\begin{array}{c}\text { Conversion } \\
\text { amount }\end{array}$ & 2350000 & 2378000 & 2420000 & 2452500 & 2500000 & 2535000 & 2550000 & 2560606 \\
\hline Acc.ExR & -102500 & -74500 & -32500 & 0 & 47500 & 82500 & 97500 & 108106 \\
\hline $\begin{array}{l}\text { Conversion } \\
\text { fee (TC) }\end{array}$ & 23500 & 23780 & 24200 & 24525 & 25000 & 25350 & 25500 & 25606 \\
\hline $\begin{array}{l}\text { Net CF with- } \\
\text { out hedging }\end{array}$ & 2326500 & 2354220 & 2395800 & 2427975 & 2475000 & 2509650 & 2524500 & 2535000 \\
\hline & $\mathrm{S}_{1}-\mathrm{TC}$ & $\mathrm{S}_{2}-\mathrm{TC}$ & $\mathrm{S}_{3}-\mathrm{TC}$ & $\mathrm{S}_{4}-\mathrm{TC}$ & $\mathrm{S}_{5}-\mathrm{TC}$ & $\mathrm{S}_{6}-\mathrm{TC}$ & $\mathrm{S}_{7}-\mathrm{TC}$ & $\mathrm{S}_{8}-\mathrm{TC}$ \\
\hline Generally & & & & $\mathrm{S}_{\mathrm{T}}-\mathrm{TC}=$ & u-ExD- TC & & & \\
\hline $\begin{array}{c}\text { Conversion } \\
\text { amount }\end{array}$ & & & 2420000 & 2452500 & 2500000 & & & \\
\hline Purchase & 2378000 & 2378000 & & & & 2535000 & 2535000 & 2535000 \\
\hline Acc.ExR & & & -32500 & 0 & 47500 & & & \\
\hline $\begin{array}{l}\text { Conversion } \\
\text { fee (TC) }\end{array}$ & & & 24200 & 24525 & 25000 & & & \\
\hline $\begin{array}{c}\text { Net CF with } \\
\text { hedging }\end{array}$ & 2378000 & 2378000 & 2395800 & 2427975 & 2475000 & 2535000 & 2535000 & 2535000 \\
\hline & $\mathrm{X}_{1}$ & $\mathrm{X}_{1}$ & $\mathrm{~S}_{3}-\mathrm{TC}$ & $\mathrm{S}_{4}-\mathrm{TC}$ & $\mathrm{S}_{5}-\mathrm{TC}$ & $\mathrm{X}_{2}$ & $\mathrm{X}_{2}$ & $\mathrm{X}_{2}$ \\
\hline Generally & \multicolumn{2}{|c|}{$\mathrm{X}_{1}$} & \multicolumn{3}{|c|}{$S_{\mathrm{u}}-\mathrm{ExD}-\mathrm{TC}$} & \multicolumn{3}{|c|}{$\mathrm{X}_{2}$} \\
\hline $\begin{array}{l}\text { Hedging } \\
\text { influence }\end{array}$ & 51500 & 23780 & 0 & 0 & 0 & -25350 & -10500 & 0 \\
\hline
\end{tabular}

TC Transaction costs

ExD Exchange rate difference

ExR Exchange rate

CF Cash flow

$\mathrm{S}_{\mathrm{u}} \quad$ Accounting exchange rate (= CNB rate on day of contract)

$\mathrm{S}_{\mathrm{T}} \quad$ Spot rate at maturity

BEV Break-even point

In expiration date it can come 7 situations, see Tab. 1. A spot rate level in particular variations is marked $\mathrm{S}_{1}, \mathrm{~S}_{2}, \mathrm{~S}_{3}, \mathrm{~S}_{4}, \mathrm{~S}_{5}, \mathrm{~S}_{6}, \mathrm{~S}_{7}$. A calculation of accounting exchange rate difference is simplified, of course first it would be calculated with $\mathrm{CNB}$ exchange rate of payment day, then with foreign exchange conversion rate. Here are both exchange differences united. The exchange rate at (time of) invoice issuing is marked $\mathrm{S}_{\mathrm{u}}$.

Hedging influence $=$ payoff $/$ loss from hedging means an amount which a company gets/loses thanks hedging. It is a difference between company profit without hedging and with hedging. Exchange rate loss/profit in accounting is resultant amount of cleared exchange rate differences. 
Net CF is called amount in CZK which enterprise receives after all transactions and deduction by all fees.

Break-even point is an exchange rate in amount 25,606 EUR/CZK. In this point there equal profit with hedging and without hedging by options. It is more useful don't hedge for company from this point.

The option partly covers losses incurred by exchange rate fluctuation to particular level of rate, it decreases the exchange rate from particular level. Then the final profit profile with using of zero-cost option structure looks subsequently:

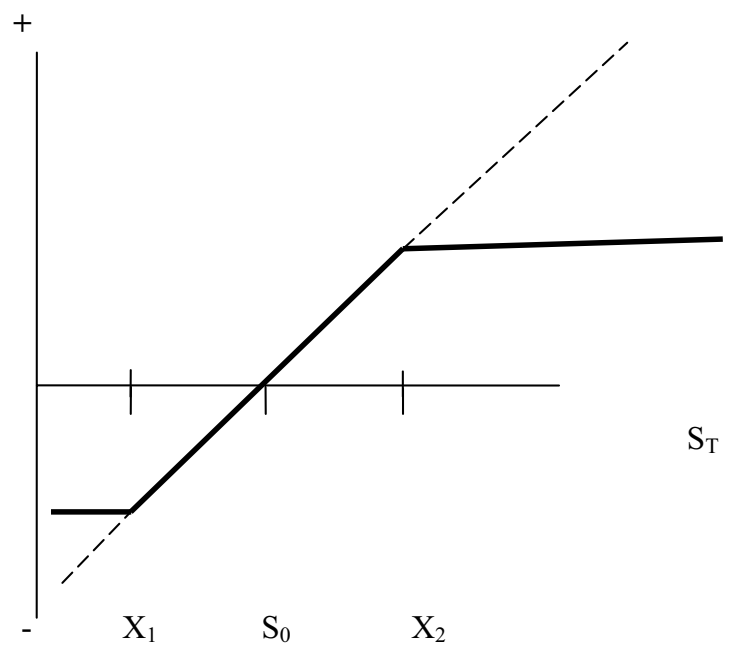

Fig. 2 - Profit profile collar with receivable including. Source: own research

$\mathrm{X}_{1} \quad$ strike of put option

$\mathrm{X}_{2} \quad$ strike of call option

$\mathrm{S}_{0} \quad$ market price on day of contract

$\mathrm{S}_{\mathrm{T}} \quad$ exchange rate on the market in time $\mathrm{T}$

Actually central part of curve is not so straight as in figure thanks to consideration of transaction costs.

Tab. 2 - Recapitulation of Citibank contract - Corridor Forward - maturity 3. Source: own research

\begin{tabular}{|c|c|c|c|c|c|}
\hline Text & Date & ČNB & $\begin{array}{c}\text { Market } \\
\text { value }\end{array}$ & Put strike & Call strike \\
\hline Date of contract & 25.3 .2011 & 24,525 & 24,55 & 23,78 & 25,35 \\
\hline Maturity date & 24.6 .2011 & 24,375 & 24,378 & & \\
\hline \multicolumn{2}{|c|}{ Change in CZK by amount } & $-0,15$ & $-0,172$ & & \\
\hline \multicolumn{2}{|c|}{ Change in \% to amount/value } & 99,39 & 99,30 & & \\
\hline
\end{tabular}


The exchange rate occured between strike prices at maturity. So, no option was exercised and the enterprise would sell in current exchange rate.

Tab. 3 - Financial impact - Citibank, Corridor Forward, maturity 3 M. Source: own research

\begin{tabular}{|c|c|c|c|}
\hline \multicolumn{2}{|c|}{ CZK } & \multicolumn{2}{c|}{ In accounting (CZK) } \\
\hline Amount in invoice & 2452500 & Sales revenue & 2452500 \\
\hline Amount of payment & 2437500 & Exch.rate loss at payment & -15000 \\
\hline Amount of exchange & 2437800 & Exch.rate profit at exchange & 300 \\
\hline & & Conversion fee $(1 \%)$ & -24378 \\
\hline Net CF & 2413422 & Net CF= real revenue of receivable & 2413422 \\
\hline
\end{tabular}

Originally booked revenue on issuing invoice in the amount of CZK 2452500 decreased after payment and exchange to $98,41 \%$ of its value, it means by $39078 \mathrm{CZK}$. It was caused by the drop in exchange rate and payment of bank fee. The influence of hedging was zero.

Identically particular situations can be evaluated on various levels of exchange rates also at contract with 6 month's maturity. Here it is presented only recapitalation of real exchange rate at maturity.

Tab. 4 - Recapitulation of Citibank contract - Corridor Forward - maturityt 6 M. Source: own research

\begin{tabular}{|c|c|c|c|c|c|}
\hline Text & Date & ČNB & Market value & Put strike & Call strike \\
\hline $\begin{array}{c}\text { Date of } \\
\text { contract }\end{array}$ & 25.3 .2011 & 24,525 & 24,55 & 23,78 & 25,30 \\
\hline Maturity date & 25.9 .2011 & 24,87 & 24,756 & & \\
\hline \multicolumn{2}{|c|}{ Change in CZK by amount } & 0,315 & 0,206 & & \\
\hline \multicolumn{2}{|c|}{$\begin{array}{c}\text { Change in \% to amount/ } \\
\text { value }\end{array}$} & 101,41 & 100,84 & & \\
\hline
\end{tabular}

The exchange rate occured between strike prices at maturity. No option was exercised and the enterprise would sell in current exchange rate. Due to increase of exchange rate, nonhedged spread was an advantage.

Tab. 5 - Financial impact - Citibank, Corridor Forward, maturity 6 M. Source: own research

\begin{tabular}{|c|c|c|c|}
\hline \multicolumn{2}{|c|}{ CZK } & \multicolumn{2}{c|}{ In accounting (CZK) } \\
\hline Amount in invoice & 2452500 & Sales revenue & 2452500 \\
\hline Amount of payment & 2487000 & Exch.rate profit at payment & 34500 \\
\hline Amount of exchange & 2475600 & Exch.rate loss at exchange & -11400 \\
\hline & 2450844 & Conversion fee $(1 \%)$ & -24756 \\
\hline Net CF & $\begin{array}{c}\text { Net CF= real revenue of } \\
\text { receivable }\end{array}$ & 2450844 \\
\hline
\end{tabular}


Originally booked revenue on issuing invoice in the amount of CZK 2452500 decreased after payment and exchange to $99,93 \%$ of its value, it means by $1656 \mathrm{CZK}$. It was again caused by the drop in exchange rate and payment of bank fee. The influence of hedging was zero.

The contract with one-year maturity had not come due at the date this paper was processed. It would be evaluated similarly.

\subsection{The offer of HSBC as of date 24.8.2011 - Collar}

Starting situation:

Receivable in accounting as of August, 8, 2011100000 EUR, or 2449500 CZK,

Exchange rate of ČNB as of August, 8, 2011 24,495 CZK/EUR,

Due date of receivable 3 months.

The enterprise wants to hedge the receivable by zero-cost option but doesn't want to sell EUR less than:

23,71 EUR/CZK, which means maximum $3 \%$ exchange rate loss, alternatively

$22,48 \mathrm{EUR} / \mathrm{CZK}$, which means maximum $8 \%$ exchange rate loss, alternatively

24,10 EUR/CZK, which means maximum 1,5\% exchange rate loss.

This value is strike price for put option $-\mathrm{X}_{1}$. There was chosen the option strategy of Collar type for this contract. HSBC states market value of 24,44 and the intended loss in \% was applied to this market value. Original instruction for the bank was that required percentages should be calculated from $\mathrm{CNB}$ exchange rate on the date when the bank evaluates a contract. Due to difference of $\mathrm{CNB}$ exchange rate and market value there are final percentages different a little bit. The Bank quoted strike price for particular put strike prices this way:

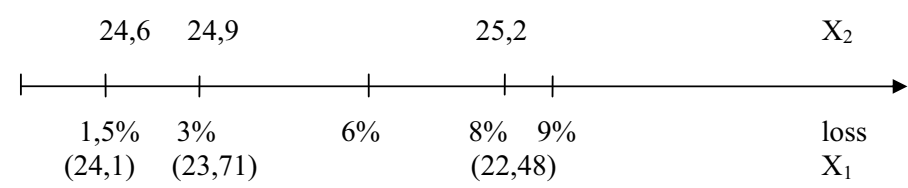

$\mathrm{X}_{1} \ldots .$. strike price of put

$\mathrm{X}_{2} \ldots \ldots$ strike price of cal

Again, time values of both options equal in this way a closed contract. Quotation corresponds to that put option is more expensive than call. It is obvious that strike price on the level $8 \%$ OTM is quite a lot for short period $(3 \mathrm{M})$. Interval is asymmetric for the enterprise. Upside is small relatively while downside is unpleasant in comparison with forward.

Break-even point in first case is an exchange rate in amount of 25,152 EUR/CZK. In this point profit with hedging and without hedging by options are equal. It is more useful to not hedge for a company from this point. 
Tab. 6 - Recapitulation of HSBC contract - Collar with intended loss 3\%. Source: own research

\begin{tabular}{|c|c|c|c|c|c|}
\hline Text & Date & ČNB & Market value & Put strike & Call strike \\
\hline Date of contract & 24.8 .2011 & 24,495 & 24,44 & 23,71 & 24,90 \\
\hline Maturity date & 24.11 .2011 & 25,695 & 25,6905 & & \\
\hline \multicolumn{2}{|c|}{ Change in CZK by amount } & 1,2 & 1,2505 & & \\
\hline \multicolumn{2}{|r|}{ Change in \% to amount/value } & 104,9 & 105,12 & & \\
\hline
\end{tabular}

The exchange rate occured above strike prices of call option at maturity. The call option was exercised and the enterprise sold EUR in strike price of 24,90 EUR/CZK. The increase in exchange rate was high.

Tab. 7 - Financial impact - HSBC with intended loss 3\%. Source: own research

\begin{tabular}{|c|c|c|c|}
\hline \multicolumn{2}{|c|}{$\mathrm{CZK}$} & \multicolumn{2}{|c|}{ In accounting (CZK) } \\
\hline Amount in invoice & 2449500 & Sales revenue & 2449500 \\
\hline Amount of payment & 2569500 & Exch.rate profit at payment & 120000 \\
\hline Amount of exchange & 2490000 & Exch.rate loss at exchange & -79500 \\
\hline & & Conversion fee $(1 \%)$ & - \\
\hline Net CF & 2490000 & $\begin{array}{c}\text { Net } \mathrm{CF}=\text { real revenue of } \\
\text { receivable }\end{array}$ & 2490000 \\
\hline
\end{tabular}

Originally booked revenue on issuing invoice in the amount of CZK 2449500 increased after payment and option exercise to $101,65 \%$ of its value, it means by $40500 \mathrm{CZK}$. The net cash flow without hedging would be 2543 359,5 CZK. It would mean increase by 93860 CZK, so to $103,83 \%$ of original invoice amount.

The profit would be higher by 53 359,5 CZK without hedging. It is net loss because of this option strategy using.

Break-even point in this case is an exchange rate in amount of 25,455 EUR/CZK. In this point profit with hedging and without hedging by options are equal. It is more useful to not hedge for a company from this point. Unfortunately, the current spot was higher than break-even point at maturity. The enterprises would loss in all three cases of HSBC contracts, see below.

Tab. 8 - Recapitulation HSBC contract - Collar with intended loss $8 \%$. Source: own research

\begin{tabular}{|l|l|l|l|l|l|}
\hline Text & Date & ČNB & Market value & Put strike & Call strike \\
\hline Date of contract & 24.8 .2011 & 24,495 & 24,44 & 22,48 & 25,2 \\
\hline Maturity date & 24.11 .2011 & 25,695 & 25,6905 & & \\
\hline Change in CZK by amount & 1,2 & 1,2505 & & \\
\hline Change in \% to amount/value & 104,9 & 105,12 & & \\
\hline
\end{tabular}

The exchange rate occured above strike prices of call option at maturity. The call option was exercised again and the enterprise sold EUR in strike price of 24,90 EUR/CZK. The increase in exchange rate was high. The difference between current spot rate and call strike was 0,495 
CZK. It shows how it was written earlier that the upside means excercise of call option already in $3 \%$ increase in exchnage rate while more than $8 \%$ drop in exchange rate should be for excercise of put option on the downside. The enterprise wouldn't conclude this contract in practice and would rather choose other hedging, e.g. forward.

Tab. 9 - Financial impact - HSBC with intended loss 8\%. Source: own research

\begin{tabular}{|c|c|c|c|}
\hline \multicolumn{2}{|c|}{ CZK } & \multicolumn{2}{c|}{ In accounting (CZK) } \\
\hline Amount in invoice & 2449500 & Sales revenue & 2449500 \\
\hline Amount of payment & 2569500 & Exch.rate profit at payment & 120000 \\
\hline Amount of exchange & 2520000 & Exch.rate loss at exchange & -49500 \\
\hline & 2520000 & $\begin{array}{c}\text { Conversion fee }(1 \%) \\
\text { CF= real revenue of } \\
\text { receivable }\end{array}$ & 2520000 \\
\hline Net CF & & in & \\
\hline
\end{tabular}

Originally booked revenue on issuing invoice in the amount of CZK 2449500 increased after payment and option exercise to $102,88 \%$ of its value, it means by $70500 \mathrm{CZK}$. The net cash flow without hedging would be 2543 359,5 CZK. It would mean increase by $93860 \mathrm{CZK}$, so to $103,83 \%$ of original invoice amount.

The profit would be higher by 23 359,5 CZK without hedging. It is net loss because of this option strategy using.

And finally, the contract concluded with the narrowest non-hedged spread was assessed subsequently.

Tab. 10 - Recapitulation of HSBC contract - Collar with intended loss 1,5\%. Source: own

\begin{tabular}{|c|c|c|c|c|c|}
\hline Text & Date & ČNB & Market value & Put strike & Call strike \\
\hline Date of contract & 24.8 .2011 & 24,495 & 24,44 & 24,10 & 24,6 \\
\hline Maturity date & 24.11 .2011 & 25,695 & 25,6905 & & \\
\hline \multicolumn{2}{|c|}{ Change in CZK by amount } & 1,2 & 1,2505 & & \\
\hline \multicolumn{2}{|c|}{ Change in \% to amount/value } & 104,9 & 105,12 & & \\
\hline
\end{tabular}

The exchange rate occured above strike prices of call option at maturity. The call option was exercised again and the enterprise sold EUR in strike price of 24,60 EUR/CZK. The difference between current spot rate and call strike was even 1,095 CZK.

Tab. 11 - Financial impact - HSBCwith intended loss 1,5\%. Source: own research

\begin{tabular}{|c|c|c|c|}
\hline \multicolumn{2}{|c|}{ CZK } & \multicolumn{2}{c|}{ In accounting (CZK) } \\
\hline Amount in invoice & 2449500 & Sales revenue & 2449500 \\
\hline Amount of payment & 2569500 & $\begin{array}{c}\text { Exch.rate profit at pay- } \\
\text { ment }\end{array}$ & 120000 \\
\hline Amount of exchange & 2460000 & Exch.rate loss at exchange & -109500 \\
\hline Net CF & 2460000 & $\begin{array}{c}\text { Conversion fee (1\%) } \\
\text { Net real revenue of } \\
\text { receivable }\end{array}$ & 2460000 \\
\hline
\end{tabular}


Originally booked revenue on issuing invoice in the amount of CZK 2449500 increased after payment and option exercise to $100,43 \%$ of its value., it means by $10500 \mathrm{CZK}$. The net cash flow without hedging would be 2543 359,5 CZK. It would mean increase by $93860 \mathrm{CZK}$, so to $103,83 \%$ of original invoice amount.

The profit would be higher by 83 359,5 CZK without hedging. It is net loss because of this option strategy using.

\subsection{The offer of UniCredit Bank as of date 9.9.2011 - Collar}

Starting situation:

Receivable in accounting as of September, 9, 2011

Exchange rate of $\check{C} \mathrm{NB}$ as of September, 9, 2011

100000 EUR, or $2443000 \mathrm{CZK}$,

Due date of receivable

24,43 CZK/EUR,

3 months.

The enterprise wants to hedge the receivable by zero-cost option but doesn't want to sell EUR less than 23,70 EUR/CZK, which means maximum $3 \%$ of exchange rate loss. Due to increase in exchange rate in the last period it doesn't relinquish possible exchange rate profits and it has evaluated hedging with strike price of put option at 22,48 EUR/CZK, which means $8 \%$ loss. It hedges a big drop in exchange rate. This value is strike price for put option - $\mathrm{X}_{1}$. The option strategy of Collar was chosen for this type of contract. UniCredit Bank quotes strike price of call option based on $\check{C} \mathrm{NB}$ exchange rate and for particular strikes this way:

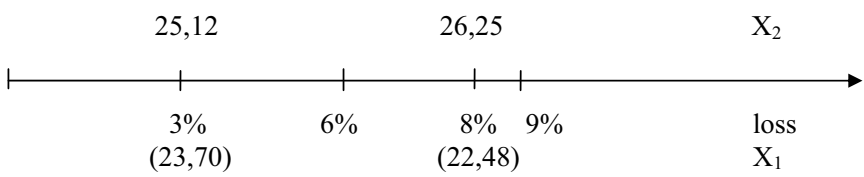

$\mathrm{X}_{1} \ldots \ldots .$. strike price of put

$\mathrm{X}_{2} \ldots \ldots \ldots$ strike price of call

Tab. 12 - Recapitulation of UniCredit Bank contract - Collar with intended loss 3\%. Source: own research

\begin{tabular}{|c|c|c|c|c|c|}
\hline Text & Datum & ČNB & Market value & Put strike & Call strike \\
\hline Date of contract & 9.9 .2011 & 24,43 & - & 23,70 & 25,12 \\
\hline Maturity date & 9.12 .2011 & 25,48 & 25,4565 & & \\
\hline $\begin{array}{c}\text { Change in CZK by } \\
\text { amount }\end{array}$ & 1,05 & - & & & \\
\hline $\begin{array}{c}\text { Change in \% to } \\
\text { amount/value }\end{array}$ & 104,3 & - & & & \\
\hline
\end{tabular}

The exchange rate occured above strike prices of call option at maturity. The call option was exercised and the enterprise sold EUR in strike price 25,12 EUR/CZK. The increase in exchange rate was higher than it was expected. The difference between current spot rate and call strike was even 0,3365 CZK. 
Tab. 13 - Finacial impact - UniCredit Bank with intended loss 3\%. Source: own research

\begin{tabular}{|c|c|c|c|}
\hline \multicolumn{2}{|c|}{ CZK } & \multicolumn{2}{c|}{ In accounting (CZK) } \\
\hline Amount in invoice & 2443000 & Sales revenue & 2443000 \\
\hline Amount of payment & 2548000 & Exch.rate profit at payment & 105000 \\
\hline Amount of exchange & 2512000 & Exch.rate loss at exchange & -36000 \\
\hline & & Conversion fee $(1 \%)$ & - \\
\hline Net CF & 2512000 & $\begin{array}{c}\text { Net CF= real revenue of } \\
\text { receivable }\end{array}$ & 2512000 \\
\hline
\end{tabular}

Originally booked revenue on issuing invoice in the amount of CZK 2443000 increased after payment and option exercise to $102,82 \%$ of its value, it means by $69000 \mathrm{CZK}$. The net cash flow without hedging would be 2520 193,5 CZK. It would mean increase by 77 193,5 CZK, so to $103,16 \%$ of original invoice amount.

The profit would be higher by 8193,5 CZK without hedging. It is net loss because of this option strategy using.

Tab. 14 - Recapitulation of UniCredit Bank contract- Collar with intended loss 8\%. Source: own rearch

\begin{tabular}{|c|c|c|c|c|c|}
\hline Text & Date & ČNB & Market value & Put strike & Call strike \\
\hline Date of contract & 9.9 .2011 & 24,43 & - & 22,48 & 26,25 \\
\hline Maturity date & 9.12 .2011 & 25,48 & 25,4565 & & \\
\hline $\begin{array}{c}\text { Change in CZK by } \\
\text { amount }\end{array}$ & 1,05 & - & & & \\
\hline $\begin{array}{c}\text { Change in \% to } \\
\text { amount/value }\end{array}$ & 104,3 & - & & & \\
\hline
\end{tabular}

The exchange rate occured between strike prices at maturity. So, no option was exercised and the enterprise was selling in current exchange rate. Broader spread paid off. The enterprise would not stay without hedging at sudden steep drop in exchange rate but broad spread allows it to participate in exchange rate increase simultaneously.

Tab. 15 - Financial impact - UniCredit Bank with intended loss 8\%. Source: own research

\begin{tabular}{|c|c|c|c|}
\hline \multicolumn{2}{|c|}{ CZK } & \multicolumn{2}{|c|}{ In accounting (CZK) } \\
\hline Amount in invoice & 2443000 & Sales revenue & 2443000 \\
\hline Amount of payment & 2548000 & Exch.rate profit at payment & 105000 \\
\hline Amount of exchange & 2545650 & Exch.rate loss at exchange & -2350 \\
\hline & & Conversion fee $(1 \%)$ & $-25456,5$ \\
\hline Net CF & 2520193,5 & $\begin{array}{c}\text { Net } \mathrm{CF}=\text { real revenue of } \\
\text { receivable }\end{array}$ & 2520193,5 \\
\hline
\end{tabular}

Originally booked revenue on issuing invoice in the amount of CZK 2443000 increased after payment and exchange to $103,16 \%$ of its value, it means by $77193,5 \mathrm{CZK}$. The influence of hedging was zero. 


\subsection{Summary}

Tab. 16 - Summary results of particular contracts. Source: own research

\begin{tabular}{|c|c|c|c|c|c|c|c|c|}
\hline Bank & Maturity & Tenor & $\begin{array}{c}\text { Put- } \\
\text { OTM }\end{array}$ & Put & Call & $\begin{array}{c}\text { Refer- } \\
\text { ence } \\
\text { rate at } \\
\text { maturity }\end{array}$ & $\begin{array}{c}\text { Exer- } \\
\text { cise of } \\
\text { option }\end{array}$ & $\begin{array}{c}\text { Selling } \\
\text { rate }\end{array}$ \\
\hline Citibank & 24.6 .2011 & $3 \mathrm{M}$ & $3 \%$ & 23,78 & 25,35 & 24,378 & not & spot \\
\hline $\begin{array}{c}\text { UniCredit } \\
\text { Bank }\end{array}$ & 9.12 .2011 & $3 \mathrm{M}$ & $3 \%$ & 23,7 & 25,12 & 25,48 & call & strike \\
\hline HSBC & 24.11 .2011 & $3 \mathrm{M}$ & $3 \%$ & 23,71 & 24,9 & 25,6905 & call & strike \\
\hline Citibank & 25.9 .2011 & $6 \mathrm{M}$ & $3 \%$ & 23,78 & 25,3 & 24,756 & not & spot \\
\hline $\begin{array}{c}\text { UniCredit } \\
\text { Bank }\end{array}$ & 9.12 .2011 & $3 \mathrm{M}$ & $8 \%$ & 22,48 & 26,25 & 25,48 & not & spot \\
\hline HSBC & 24.11 .2011 & $3 \mathrm{M}$ & $8 \%$ & 22,48 & 25,2 & 25,6905 & call & strike \\
\hline HSBC & 24.11 .2011 & $3 \mathrm{M}$ & $1,5 \%$ & 24,1 & 24,6 & 25,6905 & call & strike \\
\hline
\end{tabular}

The put option was not exercised in either one of the researched cases, when it is the main reason of hedging. But call option was exercised in 4 cases, and so the enterprise didn't realize all the potential exchange rate profit. It is visible that reference exchange rate broke strike price of call option at hedging in the autumn of 2011. It is not enough setting the put option at $8 \%$ OTM at hedging in August, with maturity in November. It shows also asymmetry in bank's evaluation besides other things, therefore banks include also their expectation into evaluation. Also Black (1973) mentioned this asymmetry. Schmock et al. (2002) states that options with discontinuous payoffs are generally traded above their theoretical Black-Scholes prices because of the hedging difficulties created by their large delta and gamma values. Considering the impossibility of exact forecast exchange rate course how Král (2003) mentioned and as well, asymmetry of evaluation from the bank's side, the enterprise has a very small chance to exercise the option. In addition, quality of prediction is significantly affected by the forecasting horizon and realized volatility model (Chan, 2010).

Accounting transactions connected with receivable, its payment and exchange to CZK were already indicated in previous examples. When closing of accounts is between date of issuing of invoice and date of its payment, then time difference between revenue and income (cash inflow) of receivable can radically impact on financial statements and amount of financial result in them. The enterprises who choose options (or other derivatives) for hedging can compensate for negative impacts in financial statements. Hedging by options requires also calculation of fair value of derivative and calculation of efficiency which is problem especially for Small and medium-sized enterprises. Big auditor's companies offer services also in this area but it is not available for most Small and medium-sized enterprises both due to price and due to demands which place these sophisticated process. 
In the paper there was analysed the option structure collar. From it follows that it is better for enterprise to place strike price X1 at minimum OTM to exercise put option on as the smallest change as possible while X2 as much as possible OTM. In order to equalize both premiums it is necessary to adjust the influence on their price. It can be done by 2 ways:

- To decrease volume of underlying asset - then we are talking about „leveraged“ structure.

- To decrease number of possible situations (probability) for option exercise - the point is principle of exotic option.

Both ways can be combined which banks often applied in their strategies. The combinations can consist of not only vanilla (standard) options but also exotic. Based on the analyse of bank products it is possible to say that the most used options for construction of zero-cost option strategies are barrier options, besides standard put and call option. Sometimes also other types of options are included to the option constructions. One of them is digital option. Most of options, for example previously mentioned barrier options, are cheaper than standard options as call and put. Then banks can offer more advantageous rate. Sometimes in strategy there are included options which are more expensive than standard calls and puts, for example extendible options.

Also it shows that not all enterprises can use options. The banks have set in their conditions minimum amount 50000 EUR (or equivalent in other currency), even 100000 EUR or 500 000 EUR on structured products. It eliminates small enterprises from using options. Forwards remain them to hedge currency risk.

And are they really zero-cost? As for initial fee, than yes. It is necessary to take into consideration that there is necessary general agreement with bank for option trading. It must be covered by collateral. There are also costs of contract processing, expert's opinions for assets evaluation, opportunity costs influencing of pledge, also of call option sale... Any zero-cost options are not really zero.

\section{CONCLUSION}

The paper has demonstrated the usage of zero-cost collar strategy in hedging of sales, it means hedging against the exchange rate drop of currency. It has been presented in model situation where the put strike was defined and Komerční banka, HSBC and UniCredit Bank evaluated the call option.

The results show that the put option was not exercised in either one of the researched cases, and so positive effect of hedging didn't become evident - limitation of loss. The hedging by collar was chosen even in different periods in the same conditions, for differently long period at the same starting situation, or at differently set spread. By contrast, the hedging led, in four out of seven cases, to exercise of call option which means to the limitation of profit. It has resulted in the conclusion that it is difficult for enterprises, especially for small and middle-sized, to set the contract conditions then there particularly exists a small probability of put option exercise.

The collar is not the only structure which is possible to set as zero-cost. That is why the research has also shortly applied to the offer of other zero-cost options structures, its accessibility and expediency for the enterprises. It has been found out that an offer of Czech banks in area of 
option structures is broad and it is only base for construction of complex derivatives which are created based on needs of client. It is possible to say that considering conditions which a client has to fulfil (mainly contract volume) the offer of complicated, structured financial derivatives refers to big enterprises in particular.

It has been also found out that the zero-cost strategies entail costs with it. Except for opportunity costs in form of unrealized profit another costs are fees connected with security and guarantee of contract. It has followed from research that it is important the enterprise should follow its strategy and goals in currency risk management, not be under pressure of banks and other subjects and their concepts how it is necessary to manage risk. Although the zerocost options are attractive for enterprises in last years and they seems to be good ,insurance“ against exchange rate fluctuation on the market, How the practical examples and other result of research has showed the chance to exercise option to the benefit of enterprise doesn't have to be big. The enterprise has suffered the loss in the most cases.

\section{References}

1. Amaitiek, O.F.S., Bálint, T., \& Rešovský, M. (2010). The Short Call Ladder strategy and its application in trading and hedging. Acta Montanistika Slovaca, 15 (5), 171-182.

2. Ambrož, L. (2002). Oceñování opcí. Praha: C.H. Beck.

3. Black, F., Scholes, M. (1973). The Pricing of Options and Corporate Liabilities. The Journal of Political Economy, 81 (3), 637-654. http://dx.doi.org/10.1086/260062

4. Dubil, R. (2010). The Varying Cost of Options and Implications for Choosing the Right Strategy. Journal of Financial Planning, 23 (5), 62-70.

5. Finley, B., \& Pettit, J. (2011). Creating Value at the Intersection of Sourcing, Hedging and Trading. Journal of Applied Corporate Finance, 23 (4), 83-89. doi:10.1111/j.1745-6622.2011.00354. $\mathrm{X}$

6. Fontanills, G.A. (2005). The Options Course. High Profit \& Low Stress Trading Methods. Second Edition. New Jersey: John Wiley \& Sons.

7. Hull, J.C. (2002). Fundamenals of Futures and Options Markets. New Jersey: Finacial Times / Prentice Hall.

8. Chan, W.H., Cheng, X., \& Fung, J. K. W. (2010). Forecasting Volatility: Roles of Sampling Frequency and Forecasting Horizon. The Journal of Futures Markets, 30 (12), 1167-1191. doi: 10.1002/fut.20476

9. Chung, S., Shih, P., \& Tsai, W. (2010). A Modified Static Hedging Method for Continuous Barrier Options. The Journal of Futures Markets, 30 (12), 1150-1166. doi:10.1002/fut.20451

10. Jílek, J. (2005). Finanční a komoditní deriváty v praxi. Praha: GRADA.

11. Khil,J., \& Suh, S. (2010). Risk management Lessons from „Knock-in Knock-out“ Option Disaster. Asia-Pacific Journal of Financial studies, 39 (1), 28-52. doi:10.1111/j.2041-6156.2009.00002. $\mathrm{X}$

12. Král, M. (2003). Devizová riqiika a jejich efektivní rǐzení ve firmě. Praha: VOX.

13. Muller, A., \& Verschoor, V.F.C. (2006). European Foreign Exchange Risk Exposure. Europen Financial Management, 12 (2), 195-220. doi:10.1111/j.1354-7798.2006.00316.x 
14. Schmock, U., Shreve, S.E., \& Wystup, U. (2002). Valuation of exotic options under shortselling constraints. Finance and Stochastics, 6 (2), 143-172. doi:10.1007/s007800100050

15. Stein, J.C. (2009). Presidential Address: Sophisticated Investors and Market Efficiency. The Journal of Finance, 64 (4), 1517-1548. doi:10.1111/j.1540-6261.2009.01472.x

16. Šoltés, V., \& Amaitiek, O.F.S. (2010). Inverse Vertical Ratio Put Spread Strategy and its Application in Hedging against a Price Drop. Journal of Advanced Studies in Finance, 1 (1), 100-107.

17. Šoltés, V., \& Amaitiek, O.F.S. (2010). The Short Put Ladder Strategy and its Application in Trading and Hedging. Club of Economics in Miscolc TMP, 6 (2), 77-85.

18. Šoltés, V., \& Rusnáková, M. (2010). Utilization of options in the formation of structured product. Transactions of the Universities of Kosice, 65-72.

\section{Contact information}

Ing. Marie Bartoňová

Tomas Bata University in Zlin, Faculty of Management and Economics

Mostni 5139, 76001 Zlín

Tel: +420 777154245

E-mail:mabartonova@seznam.cz.

JEL Classification: G32 